\title{
High performance work systems and workplace performance in small, medium-sized and large firms
}

\begin{abstract}
This paper draws on the Organisational Growth and Development (OGD) lifecycle model to extend understanding of congruence or 'best fit' theory within strategic human resource management (SHRM) debates on the relationship between high performance work systems (HPWS) and performance. With reference to management control theory, economies of scale and the availability of specialist managerial skills, the paper hypothesises that while an HPWS-performance relationship might exist in small, medium-sized and large firms, the relationship will be stronger in large firms than in both small and medium-sized firms, and stronger in medium-sized firms than in small firms. Analysis of data from the British Workplace Employment Relations Survey demonstrates, however, that there is no association between HPWS and workplace performance in mediumsized firms, in contrast to the positive relationship between HPWS and performance found in large firms and between HPWS and labour productivity in small firms.
\end{abstract}

\section{Keywords}

HPWS, small and medium-sized enterprises (SMEs), performance, best fit, organisational growth and development 


\section{Introduction}

Extensive strategic human resource management (SHRM) research over the past 20 years has suggested that the human resource management (HRM) practices a firm adopts play a critical role in determining its effectiveness. Research has generally supported the 'best practice' perspective, which suggests that integrated high performance work systems (HPWS) incorporating a range of practices such as selective hiring, extensive training, employee involvement and teamworking will impact positively on firm performance (Becker and Huselid, 1998; Combs et al., 2006; Guest, 2011).

The alternative congruence or 'best fit' perspective, by contrast, proposes that HPWS-performance relationship will be contingent on organisational context (the firm's business strategy or industrial sector (Datta et al., 2005), for example). Also from the 'best fit' perspective, the Organisational Growth and Development (OGD) lifecycle model (Baird and Meshoulam, 1988) suggests that a further important factor on which the HPWS-performance relationship might be contingent is firm size. In particular, it suggests that the importance (and hence performance advantages) of HPWS will become greater as firm size increases, given the heightened organisational complexity that firms face as they grow from being small firms at stage 1 (initiation) into medium-sized firms at stage 2 (functional growth) before reaching maturity as larger firms. This paper draws on the 2004 Workplace Employment Relations Survey (WERS 2004) (DTI, 2005) to explore this issue.

The paper contributes to the SHRM literature in a number of ways. First, most of the research on the HPWS-performance relationship has studied large firms, while small and medium-sized enterprises (SMEs) have received relatively little attention (Carlson et al., 2006: 532; Faems et al., 2005: 677; Heneman et al., 2000). This might be considered a significant oversight given the economic importance of SMEs, which in Britain, for 
example, account for $59 \%$ of private sector employment and $48 \%$ of private sector output (Department for Business Innovation and Skills, 2013). By adding to the literature on the HPWS-performance relationship in SMEs, therefore, the paper might be viewed as making an important contribution.

Second, rather than evaluating the HPWS-performance relationship in the SME sector en masse, the paper explores the relationship within small firms and medium-sized firms separately. Studies of the HPWS-performance relationship in SMEs have typically combined small and medium-sized firms into a single category (Cardon and Stevens, 2004; Sheehan, 2014; Teo et al., 2011: 2523), or alternatively have defined small firms as having fewer than 100 employees (see, for example: Chadwick et al., 2013; Sels et al., 2006). Hence, there has been little opportunity to date to test the propositions stemming from the OGD model (Baird and Meshoulam, 1988) that the HPWS-performance relationship will differ for small firms at stage 1 (initiation) and medium-sized firms at stage 2 (functional growth). By addressing this issue, therefore, this paper might be viewed as making a further distinct contribution to the literature. Additionally, by exploring the HPWS-performance relationship in medium-sized firms as a distinct category, the analysis has particular contemporary policy relevance given recent calls to recognise the importance of the 'forgotten' medium-sized firm sector in delivering national economic growth (CBI, 2011). In accordance with existing SME size definitions (Department for Business Innovation and Skills, 2013; European Commission, 2003; OECD, 2005), small firms are defined in this paper as having between 5 and 49 employees, and medium-sized firms are defined as having between 50 and 249 employees. 


\section{The HPWS-performance relationship in small, medium-sized and large firms}

As mentioned above, SHRM research has generally supported the universalistic 'best practice' argument that HPWS incorporating an integrated range of practices impacts positively on firm performance. This research is regarded as supporting the resource-based view (RBV) of the firm whereby the internal characteristics of organisations, specifically the manner in which human resources are managed, are seen as providing a potential source of sustainable competitive advantage (Becker and Huselid, 1998; Combs et al., 2006: 504; Guest, 2011: 5).

There is, however, significant debate over whether the HPWS-performance relationship holds in the SME sector. One line of argument is that HPWS are as important for competitive advantage in SMEs as for larger firms in ensuring the recruitment, development, retention and motivation of employees (Way, 2002). SMEs are often more labour intensive than larger firms, hence they might deem employee performance management to be particularly important (Chadwick et al., 2013: 313; Patel and Conklin, 2005; Sels et al., 2006). Also, the replacement costs associated with labour turnover might be especially difficult for resource-constrained SMEs to bear (Patel and Conklin, 2005), hence HPWS may be important to ensure such turnover is minimised. Furthermore, the resource constraints SMEs experience may mean that investments in HPWS will be more carefully considered and fully implemented than in larger firms (Sheehan, 2014). As such, where they are implemented, they are likely to be particularly effective.

Several studies have provided empirical support for this line of argument, with HPWS having been found to raise labour productivity, reduce voluntary turnover and increase sales growth in SMEs (Carlson et al., 2006; Deshpande and Golhar, 1994; Messersmith and Guthrie, 2010; Patel and Conklin, 2012; Sels et al., 2006; Way, 2002). 
Other studies have found HPWS to be positively related to profitability in small firms (Razouk, 2011; Sels et al., 2006: 319; Sheehan, 2014). Given this, one might argue that HPWS will have a positive impact on performance in SMEs as well as in large firms. Hence, we hypothesise:

Hypothesis 1: HPWS are positively related with performance in small, medium-sized and large firms

At the same time, however, there are arguments from a 'best fit' OGD lifecycle perspective (Baird and Meshoulam, 1988) suggesting that the HPWS-performance relationship will be stronger in large firms than in both small firms at stage 1 (initiation) and medium-sized firms at stage 2 (functional growth), and also that the HPWSperformance relationship will be stronger in medium-sized firms than in small firms.

Drawing on management control theory (Snell, 1992: 294), one such argument is that in small firms, owner-managers will typically exercise control via frequent personal interactions with employees and will tend to make all decisions concerning hiring, communication, managing performance and salaries (Baird and Meshoulam, 1988). Given this, HPWS may be considered overly bureaucratic and unnecessary in small firms, and they may have little to gain from their introduction (Chadwick et al., 2013: 312, 316; Kotey and Slade, 2005).

Firms at stage 2 (functional growth) of the OGD model may, however, require a different approach. Given that they have more employees than firms at stage 1, it will no longer be possible for owner-managers to make all decisions personally and exercise direct workforce control via personal interaction. They might also experience greater coordination and integration problems stemming from more hierarchical management 
structures and more inter-related job tasks (Greiner, 1972; Rutherford et al., 2003; Scase, 2005; Serrasqueiro and Nunes, 2008; Tocher and Rutherford, 2009). As such, the introduction of formal HR practices may become necessary to ensure that employees are appropriately developed and motivated, and are treated fairly and consistently by line managers (Baird and Meshoulam, 1988; de Kok et al., 2006: 445; Kotey and Slade, 2005; Messersmith and Guthrie, 2010). Therefore, given that HPWS have the scope to help firms manage workforce control, co-ordination and integration problems as they move from stage 1 (initiation) to stage 2 (functional growth), medium-sized and (in particular) large firms may have more to gain from their introduction than small firms.

Beyond this, however, arguments relating to economies of scale and to managerial skills and capacity might also be pertinent in theorising the HPWS-performance relationship from an OGD perspective. Where economies of scale are concerned, both medium-sized and large firms benefit from greater economies than small firms, hence they can spread the costs associated with the development and operation of HPWS over a larger workforce size (de Kok et al., 2006: 445; Patel and Conklin, 2010: 209; Sels et al., 2006: 321; Serrasqueiro and Nunes, 2008). Given this, the likelihood of a positive financial return from HPWS will be greater. Supporting this argument, Faems et al. (2005) and Way (2002) fail to identify a relationship between HPWS and financial performance in SMEs, arguing instead that the costs associated with the introduction and operation of such practices cancel out the benefits stemming from their productivity-enhancing effects. However, while medium-sized firms have greater economies of scale than small firms, they have fewer such economies than large firms. As such, one might theorise that although medium-sized firms are more likely to secure financial returns from HPWS than are small firms, they are less likely to secure such returns than are large firms. 
Where managerial skills and capacity are concerned, small firms are likely to suffer greater resource poverty than medium-sized firms and large firms (de Kok et al., 2006; Storey and Westhead, 1997). This will limit their scope to recruit the specialist managerial expertise necessary to ensure HPWS are implemented and operationalised in a manner that enables their performance-enhancing potential to be maximised (Patel and Conklin, 2012: 208). As Forth et al. (2006: 21) and Messersmith and Guthrie (2010: 243) argue, most small firms lack the resources to employ an HR specialist, yet where such a specialist is absent, general managers will pay only limited attention to HR concerns given the wide range of other day-to-day tasks for which they have responsibility (Chadwick et al., 2013: 314). This will arguably limit the ability of small firms to manage and administer HPWS in a performance-maximising manner.

However, while this lack of managerial skills and capacity may be particularly apparent in small firms, it may also be more apparent in medium-sized firms than in large firms (Sels et al., 2006: 326). Forth et al. (2006: 21-22) find, for example, that although medium-sized firms are more likely to employ an HR specialist than are small firms, they are less likely to employ such specialists than large firms. Also notable is that mediumsized firms are the greatest users of employment advice from external bodies. This, Forth et al. (2006: 93) argue, reflects the intermediate position of these firms in terms of 'having a greater number of personnel issues to handle than small firms but not yet having the fully developed personnel structures of large firms'. Hence, while medium-sized firms may have more to gain from HPWS than small firms given their greater co-ordination and integration problems (as discussed above), they are also likely to lack the managerial resources available to large firms to be able to optimise HPWS design. This further suggests that the pay-offs from HPWS may be more limited in medium-sized firms than in large firms. 
As the above discussion highlights, therefore, drawing on arguments concerning management control theory, economies of scale and managerial skills and capacity to extend theorisation from an OGD perspective (Baird and Meshoulam, 1988), one might argue that while an HPWS-performance relationship may exist within both small firms at stage 1 (initiation) and medium-sized firms at stage 2 (functional growth), it is likely to be stronger in large firms. One might also argue that the relationship will be stronger in medium-sized firms than in small firms. Given this, we hypothesise:

Hypothesis 2a: The positive relationship between HPWS and performance in large firms is stronger than in small and medium-sized firms.

Hypothesis 2b: The positive relationship between HPWS and performance is stronger in medium-sized firms than in small firms.

\section{Methods}

\section{Data and sample}

As indicated above, the paper uses data from the government-sponsored WERS 2004 management survey. WERS is nationally representative of British workplaces with five or more employees within Standard Industrial Classification major groups $\mathrm{D}$ to $\mathrm{O}$ (agriculture, hunting, forestry and fishing and mining and quarrying are excluded). The respondents are the most senior managers within the workplace with responsibility for employee relations matters.

The survey comprises 2,295 workplaces with a response rate of 64\% (Kersley et al., 2005). 589 workplaces are in the public sector and are therefore excluded from the analysis. The remaining 1,706 private sector workplaces are classified into three firm size 
categories: small, medium-sized and large. As stated above, small firms are defined as having 5-49 employees ${ }^{1}$, medium-sized firms as having between 50 and 249 employees, and large firms as having 250 or more employees (Department for Business Innovation and Skills, 2013; European Commission, 2003; OECD, 2005) ${ }^{2}$. Workplaces within this categorisation can either be single independent establishments (whereby the whole firm consists of a single workplace) or alternatively they can belong to a larger organisation. In the latter instance, it is the size of the larger organisation that is important in determining how the workplace is classified. Also, given that the WERS organisational size question asks how many employees in total are in the organisation within the UK, foreign-owned workplaces and those with overseas subsidiaries are dropped from the small and mediumsized categories to ensure firms that might have large overseas operations are excluded. This results in the exclusion of 23 observations. In addition, 119 workplaces that do not report information on whether they are subsidiaries (38 observations) or on firm size (81 observations) are excluded. This results in a sample size of 1,564 private sector workplaces classified into 1,010 large firms, 185 medium-sized firms, and 369 small firms.

\section{Measures}

Dependent variables. As Messersmith and Guthrie (2010: 244) argue, a range of outcomes are important to SME performance, and given this, the dependent variables here focus on four performance outcomes, of which two are proximal HR outcome measures (absence rate and labour turnover) and two are distal outcomes (labour productivity and financial performance). Such measures feature regularly in both the HPWS-performance literature (Combs et al., 2006) and the SME literature. Appendix 1 contains details of the means of the dependent variables. Where the two HR outcome measures are concerned, absence rate 
is measured as the percentage of working days lost through employee sickness or absence. Labour turnover is measured as the percentage of voluntary resignations on the part of employees. Where the labour productivity and financial performance measures are concerned, respondents were asked to rate the performance of their workplace relative to other workplaces in the same industry on a five-point Likert scale where $1={ }^{\text {' }}$ a lot below average' and 5='a lot better than average'. The reliability of such measures has been demonstrated in studies that suggest average positive correlations from 0.4 to 0.6 between subjective and objective performance measures (Wall et al., 2004: 113). In addition, analyses using both subjective and objective performance measures have been found to produce similar results in modelling the determinants of workplace performance within the WERS dataset (see: Forth and McNabb, 2008).

Independent variable. The independent HPWS variable is based on the 17 practices described in Appendix 2. These practices have been commonly identified as important within previous research (Combs et al., 2006) and are consistent with the conventions that have emerged within previous studies of HPWS using the WERS data (see, for example: Michie et al., 2008; Wood and Bryson, 2009; Wood and de Ménezes, 2008).

To develop a single HPWS measure, the 17 practices described in Appendix 2 were combined into a single index using confirmatory factor analysis (CFA). The fit of the CFA was good with fit indices $(\mathrm{CFI}=0.945$; $\mathrm{TLI}=0.938$; $\mathrm{RMSEA}=0.024)$ all above the recommended values (Bentler and Chou, 1987). The reliability of the HPWS index was also good (Cronbach alpha $=0.72)$ and above the recommended threshold ${ }^{3}$. Factor loadings were used to compute a weighted composite measure. They were all significant and ranged from 0.3 (for job security) to 0.7 (for employee attitude surveys). The contribution of each practice to the factor was thus based on the correlation between the 
practice and the latent variable (the factor) representing HPWS. This approach accounts for the fact that practices were measured using a combination of dichotomous, categorical and count measures (with different scale lengths). The HPWS index ranged from a minimum possible score of zero to a maximum possible score of 42 .

Controls. Several controls for workplace characteristics as commonly used in both the small firm and SHRM literature are included in the analysis. These are: industry (manufacturing), workplace age, workplace size, family-ownership, the degree of product market competition and union recognition (see Appendix 1 for further details).

\section{Analytical procedure}

To address Hypothesis 1, a series of multiple regression analyses were estimated for each firm size category, with a separate regression being estimated for each performance variable. Hence, if superscript (g) denotes the group (i.e. the size category), the regression model is:

$$
\begin{aligned}
& \operatorname{PERF}_{i}^{(g)}=\alpha^{(g)}+\beta^{(g)} H P W S_{i}^{(g)}+\sum_{1}^{k} \gamma_{k}{ }^{(g)} C T R O L_{i k}^{(g)}+\epsilon_{i}^{(g)}, \\
& g=1,2,3 ; i=1,2, \ldots, \mathrm{n}_{\mathrm{g}} ; k=1,2, \ldots, K
\end{aligned}
$$

where the subscript ' $i$ ' denotes the workplace; PERF represents each of the performance variables, CTROL are the set of ' $\mathrm{k}$ ' control variables (i.e. workplace characteristics), $\beta$ and $\gamma_{\mathrm{k}}$ are the regression coefficients associated with the HPWS and the ' $\mathrm{k}$ ' control variables, respectively, and $\varepsilon_{\mathrm{i}}$ is the error term. Where labour turnover and absence rate are concerned, the distribution of the dependent variable is censored at zero. Given this, censored regression analysis was used. Where the financial performance and labour 
productivity dependent variables are concerned, given the categorical nature of these variables ordered probit was used.

As all the measures come from a single source, there is potential for common method variance (CMV). Given this, following Podsakoff et al. (2003), a Harman's single factor test using CFA was conducted to identify whether all the variables in the analysis load onto a single factor. There was no support for this, however. Podsakoff et al. (2003) also suggest that CMV can result from the proximity of the location of items within a questionnaire. This is unlikely to be an issue in WERS, given that there is significant distance between the performance outcome items and the (diffuse) sections containing HPWS items. Hence, there is no reason to assume that responses to performance outcome items will be influenced by responses to the HPWS items as a result of CMV.

To address Hypotheses 2a and $2 \mathrm{~b}$ a multiple-group (MG) analysis was conducted to test for differences in the magnitude of the HPWS-performance relationship between the firm size categories. The HPWS-performance relationships for small, medium and large firms were estimated together and then chi-square difference tests were conducted to assess differences in the slope parameters for each group. This approach is similar to using regression analysis with dummy variables for each group, but also has the advantage of allowing for heteroskedastic residuals.

To protect the inferences from possible selection bias due to missing data (and to avoid a significant reduction in the sample size), the analysis was based on full information maximum likelihood (ML) with missing data (Arbuckle, 1996). The missing at random (MAR) assumption that patterns of missing data are independent of the unobserved data (Rubin, 1976) was thus adhered to. This allowed 720 observations to be kept in the analysis that would otherwise have been excluded had listwise deletion been used $^{4}$. Standard errors and scaled $\chi^{2}$ statistics are reported (Satorra and Bentler, 1994) that 
are robust for possible deviations from the normality assumption. The scaled difference $\chi^{2}$ tests were computed using Satorra and Bentler's (2001) procedure. The analysis was carried out using MPlus 7.1 SEM software (Muthén and Muthén, 1998-2012). The data were weighted throughout to account for the complex nature of the WERS survey design.

\section{Results}

\section{Descriptive analysis}

Variable means are given in Appendix 1. These demonstrate that the means for the HPWS measure vary between the small, medium and large firm groups, with HPWS being more widely adopted in large firms than in small and medium-sized firms, but being more widely adopted in medium-sized than in small firms. These differences are all statistically significant at the 1 per cent level, and these differences remain when controls are added for manufacturing industry, workplace age, workplace size, family-ownership, the degree of product market competition and union recognition. While these findings support the argument in the literature that the adoption of HPWS in SMEs is generally somewhat limited (Dundon and Wilkinson, 2003), it also supports the argument that the extent of adoption of such practices within the SME sector varies by firm size, with small firms being less likely to adopt HPWS than medium-sized firms as well as large firms (de Kok, 2006: 445; Forth et al., 2006; Kotey and Slade, 2005).

\section{Assessing the HPWS-performance relationship by firm size}

The paper's first hypothesis (that HPWS are positively associated with performance in small, medium-sized and large firms) is tested, as described earlier, by separate regression equations evaluating the relationship between the HPWS measure and a range of performance outcomes for each firm size category. 


\section{INSERT TABLE 1 HERE}

Table 1 shows that, in the full sample, the HPWS measure is associated with higher levels of labour productivity $(\beta=-0.016, p$-value $<0.01)$ and financial performance $(\beta=-0.016, p$ value $<0.05$ ) but not with lower levels of labour turnover or employee absence. In large firms, as anticipated, the HPWS measure is associated with lower labour turnover $(\beta=-$ 0.009 , $p$-value $<0.01)$, higher labour productivity $(\beta=0.028, p$-value $<0.01)$ and enhanced financial performance $(\beta=0.025, p$-value $<0.01)$. It is not, however, associated with lower absence. In small firms, the HPWS measure is not associated with absence, labour turnover or financial performance, although it is positively associated with labour productivity $(\beta=0.021, p$-value $<0.05)$.

However, where medium-sized firms are concerned, there is no evidence of an association between the HPWS measure and any of the performance measures. Indeed, opposite to expectations, the HPWS coefficient is positive (but non-significant) for labour turnover while for the other performance variables the relationship is negative (but nonsignificant). Therefore, while the HPWS measure is positively associated with three of the four performance measures in large firms, and positively associated with labour productivity in small firms, there is no evidence that it is positively associated with any of the performance measures in medium-sized firms. Therefore, while Hypothesis 1 is largely supported for large firms and (to a limited extent) for small firms, it is not supported for medium-sized firms.

Assessing differences in the size of the HPWS-performance relationship between firm size categories 
With regard to Hypotheses $2 \mathrm{a}$ and $2 \mathrm{~b}$, Table 2 reports the results of the series of difference $\chi^{2}$ tests for nested models between the baseline model (MG0) in which all parameters are freely estimated for each group (equation [1]) and the restricted models (MG1) with $\beta$ constrained to be equal between each paired comparison.

\section{INSERT TABLE 2 HERE}

From the reported twelve $\chi^{2}$ statistics (three comparisons for each performance variable), in six cases, the null hypothesis of equality of the regression parameters across groups (i.e. no significant differences in the strength of the HPWS-performance relationship across groups) is rejected.

In particular, the analysis finds significant differences in the influence of the HPWS measure on labour turnover in large vs. small firms $(\Delta \chi 2=7.10, p$-value $<0.007)$, large vs. medium-sized firms $(\Delta \chi 2=236.97, p$-value $<0.000)$, and medium-sized vs. small firms $(\Delta \chi 2=90.09, p$-value $<0.000)$. This suggests that the magnitude of the negative relationship between HPWS and labour turnover is significantly greater in large firms than in both small firms and medium-sized firms, and also that the HPWS-labour turnover relationship differs between small firms and medium-sized firms. Where labour productivity is concerned, the magnitude of the HPWS-labour productivity relationship is greater in large firms than in medium-sized firms $(\Delta \chi 2=13.40, p$-value $=0.000)$, and in small firms than medium-sized firms $(\Delta \chi 2=8.06, p$-value $=0.005)$ (as might be expected given the lack of significance in the relationship between HPWS and productivity in medium-sized firms reported in Table 1). There is no difference, however, in the magnitude of the HPWS-labour productivity relationship between small firms and large 
firms. Where financial performance is concerned, the magnitude of the HPWS-financial performance relationship is greater in large firms than in medium-sized firms $(\Delta \chi 2=4.14$, p-value $=0.042$ ) (again, as might be expected given the lack of a HPWS-financial performance relationship in medium-sized firms). However, although there is a significant positive HPWS-financial performance relationship in large firms but not in small firms, the results do not suggest that the magnitude of the relationship is significantly greater in the former than the latter.

The results therefore suggest some support for Hypothesis 2a, with there being a stronger relationship between HPWS and performance in large firms than in medium-sized firms and (to a limited extent) than in small firms. There is, however, no evidence in support of Hypothesis $2 \mathrm{~b}$ that there will be a stronger relationship between HPWS and performance in medium-sized firms than in small firms.

\section{Discussion and conclusions}

This paper set out to test two hypotheses. Drawing on universalistic 'best practice' predictions associated with the RBV, the first hypothesis was that HPWS is positively related with performance in small, medium-sized and large firms. With regard to the paper's second hypothesis, the paper extended propositions from the OGD 'best fit' perspective (Baird and Meshoulam, 1988) drawing on arguments relating to management control theory, economies of scale and managerial skills and capacity to hypothesise that the HPWS-performance relationship will be stronger in large firms than in small firms at stage 1 (initiation) and medium-sized firms at stage 2 (functional growth), and stronger in medium-sized firms than in small firms.

Where Hypothesis 1 was concerned, the analysis reported a positive association in large firms between HPWS and labour turnover, productivity and financial performance 
(but not absence levels), while in small firms a positive relationship was identified between HPWS and labour productivity but not between HPWS and absence, employee labour turnover or financial performance. Perhaps most notable, however, there was no evidence whatsoever of a relationship between HPWS and performance in medium-sized firms. Hypothesis 1 was not, therefore, supported.

In relation to Hypothesis $2 \mathrm{a}$ (that the positive relationship between HPWS and performance in large firms is stronger than in small and medium-sized firms) a stronger relationship between HPWS and performance was found in large firms than in mediumsized firms, but only limited evidence was found of a stronger relationship in large firms than in small firms. Hence, this hypothesis was only partially supported. Also, there was no evidence to support Hypothesis $2 b$ that the HPWS-performance relationship will be stronger in medium-sized firms than in small firms (as expected given the lack of evidence of a positive HPWS-performance relationship in medium-sized firms).

These results have some notable implications for both the SME literature and also for SHRM theory. Where the SME literature is concerned, the lack of a HPWSperformance relationship among medium-sized firms as found here has not been identified within previous SME research. This may be as previous studies have either combined small and medium-sized firms into a single category (Cardon and Stevens, 2004; Sheehan, 2014; Teo et al., 2011), or have taken a cut-point of 100 employees to identify small firms (Chadwick et al., 2012; Sels et al., 2006) hence have not been able to isolate the HPWSperformance relationship within the medium-sized firm size category. Either way, the differences in the HPWS-performance relationship between small firms and medium-sized firms (at least with regard to productivity outcomes) identified here add to the argument made elsewhere that it may be useful to view small firms and medium-sized firms as analytically distinct (Forth et al., 2006; Kotey and Slade, 2005), and that this may facilitate 
a more nuanced understanding of HR issues within the SME sector. In particular, the SME label may not be representative of a group of firms within which HPWS has uniform productivity effects.

Moreover, the identification of a positive relationship between HPWS and labour productivity but not financial performance in small firms is notable given its consistency with arguments made elsewhere in the SME literature that while HPWS may have productivity-enhancing effects in small firms (and may therefore be important in helping firms transition from initiation to the growth stage of development), these effects will be cancelled out in financial terms by the higher labour costs associated with the adoption of such practices (Faems et al., 2005; Way, 2002). Also notable is that the analysis found a negative association between HPWS and lower labour turnover in large firms but not in small firms. Labour turnover is considered to be a significant barrier to small firm success (Way, 2002: 769), hence the apparent inability of HPWS to address this barrier might be considered to be a matter of concern.

Where broader SHRM theory is concerned, the lack of an HPWS-performance relationship in medium-sized firms in the analysis conducted here might be viewed as presenting a challenge to the view in much of the SHRM literature of a universal 'best practice' relationship between HPWS and performance (Becker and Huselid, 1998; Combs et al., 2006; Guest, 2011). Instead, by suggesting that the HPWS-performance relationship changes as firms develop and grow, the analysis highlights the importance of OGD lifecycle models (Baird and Meshoulam, 1988; Kotey and Slade, 2005; Messersmith and Guthrie, 2010). It also suggests that the OGD model provides a useful theoretical framework for the small extant body of literature on the contingent effects of firm size on the HPWS-performance relationship (Deshpande and Golhar, 1994; Messersmith and Guthrie, 2010; Sels et al., 2006; Way, 2002), and that there may be considerable value in 
developing and empirically testing theoretical propositions from it in future SHRM research.

Indeed, with regard to theory development from an OGD perspective, the lack of any HPWS-performance relationship in medium-sized firms in the results presented here might be viewed as particularly pertinent. One possible explanation is that in their desire to professionalise their HR practices, medium-sized firms may have introduced HPWS at a faster rate than the number of employees would optimally suggest, possibly in anticipation of future growth. Also, as argued earlier, the HPWS-performance relationship might be expected to be weaker in medium-sized firms than large firms as they have fewer economies of scale (Sels et al., 2006; Way, 2002), and are unlikely to have the managerial skills and capacity of large firms (particularly specialist HR management capacity) to manage and administer HPWS in a performance-enhancing manner (CBI, 2011; Forth et al., 2006; Sels et al., 2006: 326). Extant theorising suggests that while these factors might render HPWS less effective in medium-sized firms than large firms, it will nevertheless be more effective in medium-sized firms than small firms. However, the lack of an HPWSperformance relationship in medium-sized firms in the results presented here suggests that these factors may be of a sufficient magnitude not only to render HPWS less effective in medium-sized than large firms, but also to render it less effective in medium-sized than small firms.

The results also have implications for policy and management practice, especially where medium-sized firms are concerned. If one assumes that the lack of an HPWSperformance relationship in medium-sized firms is in part due to the absence of the managerial skills and capacity necessary to establish and administer such systems in a performance-enhancing manner, the analysis implies that as firms experiencing functional growth enter the medium-sized category, they need to ensure that such skills and capacity 
are in place. This in turn suggests support for the CBI's (2011) recent calls for more government assistance in helping medium-sized firms to recruit management from outside the firm, increase the education levels of managers in the firm and invest in external advice. While it is only possible to speculate on the importance of these calls given that the analysis here does not test whether a HPWS-performance relationship emerges in medium-sized that have such management skills and capacity in place, this might nevertheless prove to be an important avenue for future research. This might also be deemed important given how little is known about HRM within the 'forgotten' mediumsized firm sector (CBI, 2011), despite the sector's crucial role in contributing towards overall economic performance.

Several caveats should be kept in mind when interpreting the results presented here. In particular, the analysis is based on cross sectional data, hence it is difficult to draw clear causal inferences. In addition, although the analysis controls for industry sector, it does not demonstrate whether the lack of an HPWS-performance relationship holds across all medium-sized firms or whether it is accounted for by firms within specific industries with particular levels of capital intensity or particular business strategies (Datta et al., 2005). Therefore, despite the advantages of the size and representativeness of the WERS data, there is a need for future research exploring the HPWS-performance relationship by firm size that draws on different data sources and different research designs in order to address these caveats. Such future research will shed further important light on the conclusions reached in this paper concerning the value of developing theoretical propositions from an OGD perspective in future SHRM research, the importance of drawing an analytical distinction between small and medium-sized firms within both academic and policy circles, and the particular barriers that medium-sized firms appear to face in securing a pay-off from HPWS. 


\section{Notes}

1. The Department for Business Innovation and Skills and EU definitions for small firms is 10-49 employees, while firms with fewer than 10 employees are classified as micro firms. However, it is not possible to exclude firms with fewer than 10 employees from the analysis as the organisational size variable within the WERS data is banded and does not have a cut-point at 10 employees.

2. SME definitions vary in different national contexts. In the US, medium-sized firms are frequently defined as having 50-499 employees (US Small Business Administration, 2003). Given this, the analysis reported below is repeated using the US definition for medium-sized firms. Using this definition, which results in 54 workplaces being reclassified as medium-sized as opposed to large, the results did not change. This paper's conclusions therefore hold irrespective of whether the US or the EU definition for medium-sized firms is used. The analysis using the US definition is available on request.

3. To assess the robustness of the HPWS index, we performed a sensitivity analysis by computing the index using other data reduction techniques (principal component analysis, unit or equal weights with standardized variables), different estimation methods (weighted least squares and maximum likelihood -with robust standard errors) and also considering practices in the CFA as both continuous and categorical indicators. The correlation between all indices was in all cases higher than 0.96 .

4. In supplementary analysis using listwise deletion, the results reported below remained virtually the same. 


\section{References}

Arbuckle, J. L. (1996). 'Full information estimation in the presence of incomplete data', in G.A. Marcoulides and R.E. Schumacker (eds.), Advanced Structural Equation Modeling: Issues and Techniques. Mahwah, NJ: Lawrence Erlbaum Associates.

Baird, L. and Meshoulam, I. (1988). 'Managing two fits of strategic human resource management'. Academy of Management Review, 13, 116-128.

Becker, B. and Huselid, M. (1998). 'High performance work systems and firm performance: a synthesis of research and managerial implications'. Research in Personnel and Human Resources Management, 16, 53-101.

Bentler, P. and Chou, C. (1987). 'Practical issues in structural modelling'. Sociological Methods \& Research, 16, 78-117.

Cardon, M. and Stevens, C. (2004). 'Managing human resources in small organizations: what do we know?' Human Resource Management Review, 14, 295-323.

Carlson, D., Upton, N. and Seaman, S. (2006). 'The impact of human resource practices and compensation design on performance: an analysis of family-owned SMEs'. Journal of Small Business Management, 44, 531-543.

Chadwick, C., Way, S., Kerr, G. and Thacker, J. (2013). 'Boundary conditions of the highinvestment human resource systems-small-firm labor productivity relationship'. Personnel Psychology, 66, 311-343.

Combs, J., Liu, Y., Hall, A. and Ketchen, D. (2006). 'How much do high-performance work practices matter? A meta-analysis of their effects on organizational performance'. Personnel Psychology, 59, 501-528.

CBI (2011). Future Champions- Unlocking Growth in the UK's Medium-Sized Businesses. London: Confederation of British Industry.

Datta, D., Guthrie, J. and Wright, P. (2005). 'Human resource management and labor productivity: does industry matter?' Academy of Management Journal, 48, 135-145.

de Kok, J., Uhlaner, L. and Thurik, R. (2006). 'Professional HRM practices in family owned-managed enterprises'. Journal of Small Business Management, 44, 441-460.

Department for Business Innovation \& Skills (2013). Business Populations Estimates for the UK and Regions 2013. Statistical Release URN 13/92.

DTI (2005). Workplace Employee Relations Survey: Cross-Section, 2004 [computer file]. Colchester: The Data Archive [distributor], 22 ${ }^{\text {nd }}$ December 1999, SN: 5294.

Deshpande, S. and Golhar, D. (1994). 'HRM practices in large and small manufacturing firms: a comparative study'. Journal of Small Business Management, 32, 49-56. 
Dundon, T. and Wilkinson, A. (2003). 'Employment relations in small firms', In B. Towers (ed.), Handbook of Employment Relations: Law and Practice (4th ed.), London: Kogan Page.

European Commission (2003). The New SME Definition. European Union.

Faems, D., Sels, L., De Winnie, S. and Maes, J. (2005). 'The effects of individual HR domains on financial performance: evidence from Belgian small businesses'. International Journal of Human Resource Management, 16, 676-700.

Forth, J., Bewley, H. and Bryson, A. (2006). Small and Medium-Sized Enterprises: Findings from the 2004 Workplace Employment Relations Survey. London: Routledge.

Forth, J. and McNabb, R. (2008). 'Workplace performance: a comparison of subjective and objective measures in the 2004 Workplace Employment Relations Survey'. Industrial Relations Journal, 39, 104-123.

Greiner, L. (1972). 'Evolution and revolution as organizations grow'. Harvard Business Review, 50, 37-46.

Guest, D.E. (2011). 'Human resource management and performance: still searching for some answers'. Human Resource Management Journal, 21, 3-13.

Heneman, R., Tansky, J. and Camp, S. (2000). 'Human resource management practices in small and medium-sized enterprises: unanswered questions and future research'. Entrepreneurship Theory and Practice, 25, 11-26.

Kersley, B., Alpin, C., Forth, J., Bryson, A., Bewley, H., Dix, G. and Oxenbridge, S. (2005). Inside the Workplace: First Findings from the 2004 Workplace Employee Relations Survey. London: Department of Trade and Industry.

Kotey, B. and Slade, P. (2005). 'Formal human resource management practices in small growing firms'. Journal of Small Business Management, 43, 16-40.

Messersmith, J. and Guthrie, J. (2010). 'High performance work systems in emergent organisations: implications for firm performance'. Human Resource Management, 49, 241-264.

Michie, J., Zubanov, N. and Sheehan, M. (2008). Human Resource Management Practices, Organisational Outcomes and Performance: an Analysis of WERS 2004 Data. London: Department for Business Enterprise and Regulatory Reform.

Muthén, L. and Muthén, B. (1998-2012). Mplus User's Guide. Seventh Edition. Los Angeles, CA: Muthén and Muthén.

OECD (2005). SME and Entrepreneurship Outlook 2005. Paris: Organisation for Economic Co-operation and Development. 
Patel, P. and Conklin, B. (2012). 'Perceived labor productivity in small firms: the effects of high-performance work systems and group culture through employee retention'. Entrepreneurship Theory and Practice, 36, 205-235.

Podsakoff, P. M., MacKenzie, S. B., Lee, J., \& Podsakoff, N. P. (2003). 'Common method biases in behavioral research: A critical review of the literature and recommended remedies'. Journal of Applied Psychology, 88, 879-903.

Razouk, A.A. (2011). 'High-performance work systems and performance of French small and medium-sized enterprises: examining causal order'. International Journal of Human Resource Management, 22, 311-330.

Rubin, D. (1976). 'Inference and missing data'. Biometrika, 63, 581-592.

Rutherford, M., Buller, P. and McMullen, P. (2003). 'Human resource management problems over the life cycle of small- to medium-sized firms'. Human Resource Management, 42, 321-337.

Satorra, A. and Bentler, P. (1994). 'Corrections to test statistics and standard errors in covariance structure analysis', in A. von Eye and C. Clogg (eds), Latent Variables Analysis: Applications for Developmental Research, Thousand Oaks, CA: Sage.

Satorra, A. and Bentler, P. (2001). 'A scaled difference chi-square test statistic for moment structure analysis'. Psychometrika, 66, 507-514.

Scase, R. (2005). 'Managerial strategies in small firms', in S. Marlow, D. Patton and M. Ram (eds) Managing Labour in Small Firms, London: Routledge.

Sels, L., De Winne, S., Maes, J., Delmotte, J., Faems, D. and Forrier, A. (2006). 'Unravelling the HPWS-performance link: value-creating and cost-increasing effects of small business HPWS'. Journal of Management Studies, 43, 319-345.

Serrasqueiro, Z. and Nunes, P. (2008). 'Performance and size: empirical evidence from Portuguese SMEs'. Small Business Economics, 31, 195-217.

Sheehan, M. (2014). 'Human resource management and performance: Evidence from small and medium-sized firms'. International Small Business Journal, 32, 545-70.

Snell, S. (1992). 'Control theory in strategic human resource management: the mediating effect of administrative information’. Academy of Management Journal, 35: 292-327.

Storey, D. and Westhead, P. (1997). 'Management training in small firms- a case of market failure?' Human Resource Management Journal, 7, 61-71.

Teo, S., Le Clerc, M. and Galang, M. (2011). 'Human capital enhancing HRM systems and frontline employees in Australian Manufacturing SMEs'. International Journal of Human Resource Management, 22, 2522-2538. 
Tocher, N. and Rutherford, M. (2009). 'Perceived acute human resource management problems in small and medium firms: an empirical examination'. Entrepreneurship Theory and Practice, 33, 455-479.

US Small Business Administration (2003). How Does the SBA Define a Small Business? www.app1.sba.gov/faqs/faqindex.cfm?areaID=15.

Wall, T., Michie, J., Patterson, M., Wood, S., Sheehan, M., Clegg, C. and West, M. (2004). 'On the validity of subjective measures of company performance'. Personnel Psychology, 57, 95-118.

Way, S. (2002). 'High performance work systems and intermediate indicators of firm performance within the US small business sector'. Journal of Management, 28, 765-785.

Wood, S. and Bryson, A. (2009). 'High involvement management', in W. Brown, A. Bryson, J. Forth and K. Whitfield (eds) The Evolution of the Modern Workplace, Cambridge: Cambridge University Press.

Wood, S. and de Ménezes, L. (2008). 'Comparing perspectives on high involvement management and organizational performance across the British economy'. The International Journal of Human Resource Management, 19, 639-682. 
Table 1: The relationship between HPWS and performance in small, medium and large firms

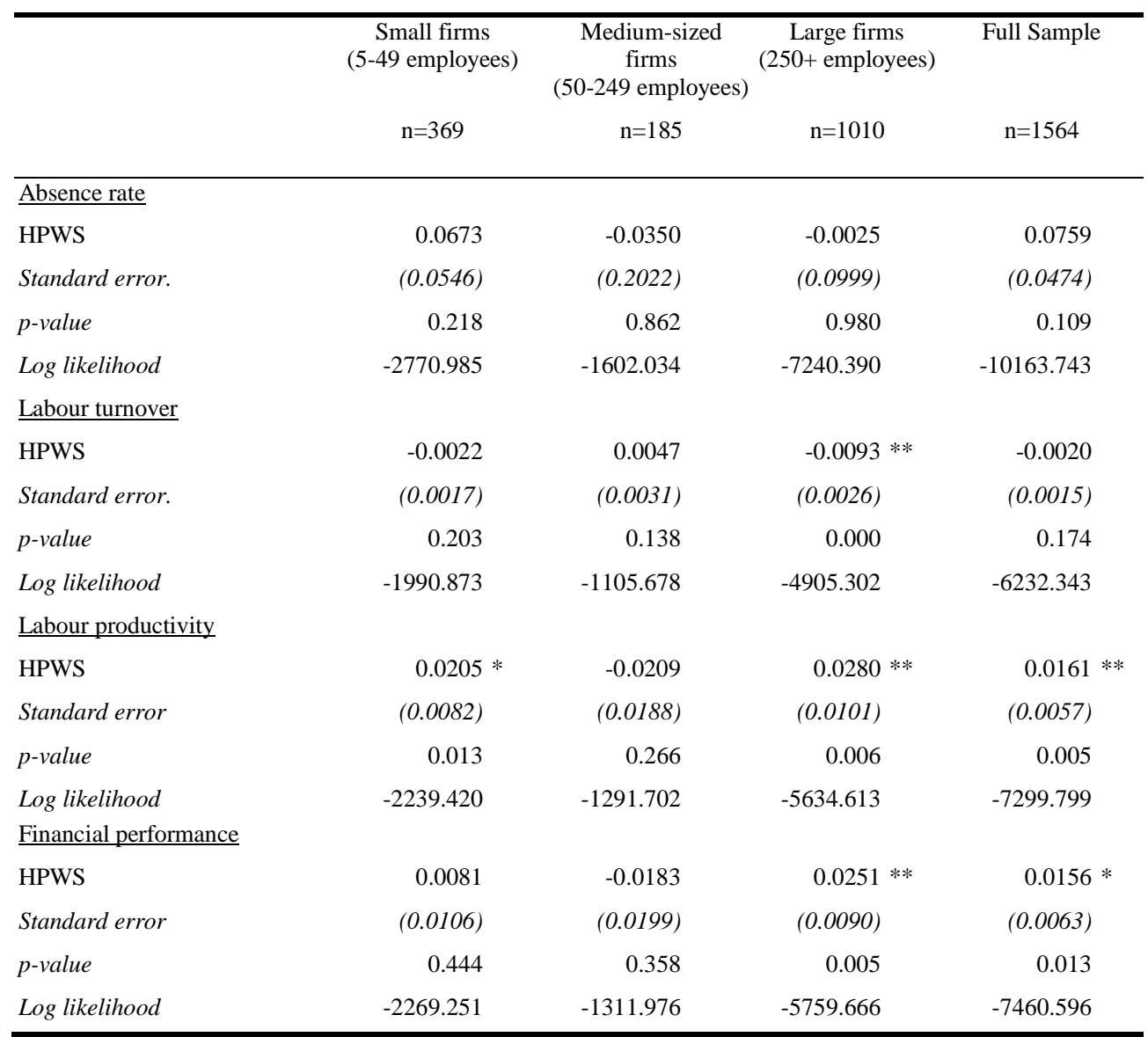

Notes: Censored regression analysis (absence rate and labour turnover). Ordered probit analysis (labour productivity and financial performance). Coefficients given.

All equations control for the manufacturing industry, workplace age, workplace size, family-ownership, degree of product market competition and union recognition.

** $p<0.01 ;{ }^{*} p<0.05$. 
Table 2: Difference Tests for equality of slope parameters

\begin{tabular}{|c|c|c|c|c|}
\hline & Absence rate & Labour turnover & Labour productivity & $\begin{array}{c}\text { Financial } \\
\text { performance }\end{array}$ \\
\hline \multicolumn{5}{|c|}{ Panel A: Large vs. small firms } \\
\hline$\Delta$ d.f. & 1 & 1 & 1 & 1 \\
\hline p-value & 0.614 & 0.007 & 0.494 & 0.175 \\
\hline \multicolumn{5}{|c|}{ Panel B: Large vs. medium-sized firms } \\
\hline$\Delta \mathrm{d} . \mathrm{f}$. & 1 & 1 & 1 & 1 \\
\hline p-value & 0.831 & 0.000 & 0.000 & 0.042 \\
\hline \multicolumn{5}{|c|}{ Panel C: Medium-sized vs. small firms } \\
\hline$\Delta \chi^{2}$ & 0.221 & 90.091 & 8.060 & 1.128 \\
\hline$\Delta$ d.f. & 1 & 1 & 1 & 1 \\
\hline
\end{tabular}




$\begin{array}{cccc}\begin{array}{c}\text { Small firms } \\ (5-49\end{array} & \begin{array}{c}\text { Medium- } \\ \text { sized firms } \\ \text { employees }\end{array} & \begin{array}{c}\text { Large firms } \\ (250+ \\ \text { employees })\end{array} & \text { Full sample } \\ \mathrm{n}=369 & \mathrm{n}=185 & \mathrm{n}=1010 & \mathrm{n}=1564 \\ 10.710 & 13.763 & 17.964 & 15.801\end{array}$

\begin{tabular}{lrrr}
\hline HPWS & 10.710 & 13.763 & 17.964
\end{tabular}

Performance measures

Absence rate

$\begin{array}{llll}3.490 & 4.438 & 5.063 & 4.607 \\ 0.146 & 0.138 & 0.157 & 0.152 \\ 3.621 & 3.512 & 3.444 & 3.491 \\ 3.476 & 3.512 & 3.617 & 3.573\end{array}$

Financial performance ${ }^{l}$

Workplace age

$0-4$ years

$\begin{array}{llll}0.114 & 0.096 & 0.082 & 0.091\end{array}$

5-9 years

0.159

0.154

0.130

10-19 years

0.269

0.213

0.197

0.140

$20+$ years

0.458

0.537

0.591

0.553

Workplace size ${ }^{2}$

5-9 employees

0.274

$\begin{array}{lll}0.130 & 0.074 & 0.124\end{array}$

10-24 employees

0.493

0.124

0.104

0.198

25-49 employees

0.233

0.124

0.110

0.141

50-99 employees

0.395

0.129

0.130

100-249 employees

0.227

0.134

0.113

250-499 employees

0.207

0.138

500+ employees

0.242

0.156

Family-ownership

Not family owned

\begin{tabular}{llll}
0.441 & 0.483 & 0.819 & 0.689 \\
0.068 & 0.132 & 0.114 & 0.104 \\
0.491 & 0.385 & 0.067 & 0.207 \\
& & & \\
0.149 & 0.195 & 0.181 & 0.179 \\
0.662 & 0.762 & 0.757 & 0.735 \\
0.043 & 0.158 & 0.467 & 0.330 \\
\hline
\end{tabular}

Manufacturing

Degree of market competition

0.043

0.158

0.330

${ }^{1}$ Compared with other establishments in the same industry

${ }^{2}$ This measure is not to be confused with organisational size. It is possible to be a small workplace (for example with $5-9$ employees) within a large firm with $250+$ employees 


\section{HPWS Items}

Sophisticated recruitment

Induction

Off-the-job training

Internal labour market

Performance-related pay

Performance appraisal

Teamwork

Team briefing

Consultation committee

Employee attitude survey

Quality circles

Functional flexibility

Benefits

Flexible working/Familyfriendly practices

Equal opportunities

Grievance procedures

Job security
Personality/attitude test or performance/competency tests in filling the largest occupational group (LOG) vacancies. $0=$ none, $1=$ one of these two, $2=$ both.

Induction programme for new non-managerial LOG employees. $0=$ no induction, $1=<1$ day, $2=1-<2$ days, $3=2-<4$ days, $=4-<6$ days, $5=6+$ days

Proportion of experienced LOG given time-off from normal daily work duties to undertake training in past 12 months. ${ }^{1}$

Vacancies filled by $0=$ external applicants only, $1=$ external applicants preferred, $2=$ applications from internal and external candidates treated equally, $3=$ internal applicants preferred, $4=$ internal applicants only.

Proportion of non-managerial employees paid-by-results or receives merit-pay. ${ }^{1}$

Proportion of non-managerial employees having performance appraised at least annually. ${ }^{1}$

Proportion of LOG working in formally-designated teams. ${ }^{1}$

Meetings between line-managers/supervisors and direct reports. $0=$ none, $1=<$ once every three months, $2=<$ monthly, $3=<$ fortnightly, $4=<$ weekly, $5=<$ daily, $6=$ daily.

Number of issues discussed within managers and employees at the workplace primarily concerned with consultation, rather than negotiation (joint consultative committees, works councils or representative forums): cumulative of production issues, employment issues, financial issues, future plans, pay issues, leave and flexible working arrangements, welfare services and facilities, government regulations, work organisation, health and safety, equal opportunities, training, other. Range $=0-13$

Formal survey in past two years and written results available to employees. Range 0-1.

Proportion of LOG involved in problem-solving groups, quality-circles or continuousimprovement-groups. ${ }^{1}$

Proportion of LOG formally trained to do jobs other than their own. ${ }^{1}$

LOG non-pay terms and conditions include: employer pension scheme; private health insurance more than four weeks of paid annual leave (excluding public holidays); sick pay in excess of statutory requirements. Range $0-4$.

Number of practices offered: home-working in normal working hours; job-sharing schemes; flexitime; female employees on maternity leave receive their normal full rate of pay; working only during school term-time; workplace nursery or nursery linked with workplace; financial help with child-care; financial help with the care of older adults; leave for carers of older adults. Range 0-9.

Number of practices used: recruitment and selection monitored or reviewed to identify indirect discrimination by gender, ethnic background, disability, age; promotion procedures monitored or reviewed to identify indirect discrimination by gender, ethnic background, disability, age. Range 0 8.

Number of practices used: a formal procedure for dealing with individual grievances raised by any employee at the workplace; employees are required to set out in writing the nature of the grievance; employees are asked to attend a formal meeting with a manager to discuss the nature of their grievance; and employees have a right to appeal against a decision made. Range 0-4.

Job security or no-compulsory redundancies policy. $0=$ no policy, $1=$ policy applies to some groups of non-management employees but not LOG, $2=$ policy applies to LOG. 